\title{
Costly Tax Enforcement And Financial Repression: A Reconsideration Using An Endogenous Growth Model
}

Rangan Gupta, University of Pretoria, South Africa

Emmanuel Ziramba, University of South Africa, South Africa

\begin{abstract}
Using a monetary endogenous growth overlapping generations model characterized by financial repression, purposeful government expenditures and costly tax enforcement, we analyze whether financial repression can be explained by the cost involved in raising taxes. Note financial repression is modeled via "high" obligatory reserve requirements that banks in the economy need to hold. We show that higher costs of tax collection produce a monotonic increase in reserve requirements. Moreover, the government tends to rely more on indirect taxation, compared to direct taxation, as costs of tax collection increases.
\end{abstract}

Keywords: Costly Tax Enforcement; Financial Repression; Endogenous Growth; Overlapping Generations Model.

\section{INTRODUCTION}

$\mathscr{Q}$ sing a Barro-type monetary endogenous overlapping generations model, characterized by costly tax enforcement and financial repression, we analyze the relationship between the costs of tax collection and financial repression. We follow the dominant trend in the literature ${ }^{1}$ in defining financial repression through an obligatory "high" reserve deposit ratio requirement, that the banks in the economy needs to maintain. ${ }^{2}$ Specifically, we analyze whether the "high" reserve requirements in a closed economy characterized by costly tax collection, are a fall out of a welfare maximizing decision of the government, which has access to income taxation and seigniorage as sources of revenue.

Given that the concern is not whether financial repression is prevalent, but the associated degree to which an economy is repressed, since developed or developing economies both resort to such restrictive policies (Espinosa and Yip (1996)), the pertinent question is - Why, if at all, would a government want to repress the financial system ? This seems paradoxical, especially when one takes into account the well documented importance of the financial intermediation process on economic activity, mainly via the finance-growth nexus. ${ }^{3}$ Besides, the fact that "high" cash reserve requirements enhances the size of the implicit tax base and, hence, is lucrative for the government to repress the financial system, alternative explanations, with varied levels of success, have ranged from: Inefficient tax systems (Cukierman et al (1992)) and Giovannini and De Melo (1993)) and tax evasion (Roubini and Sala-i-Martin (1995), Gupta (2005, 2006, 2008b) and Gupta and Ziramba (2009)) to degree of financial development (Di Giorgio

\footnotetext{
${ }^{1}$ See for example, Drazen (1989), Bacchetta and Caminal (1992), Haslag and Hein (1995), Espinosa and Yip (1996), Haslag (1998), Haslag and Koo (1999), Haslag and Bhattacharya (2001), Gupta (2005, 2006, 2008a) and Gupta and Ziramba (2008a, b, 2009) amongst others.

${ }^{2}$ Financial repression, though, can involve other set of government legal restrictions, like interest rate ceilings and compulsory credit allocation, besides, "high" reserve requirements that prevent the financial intermediaries from functioning at their full capacity level. However, given the wave of interest rate deregulation in the 1980s, and removal credit ceiling some years earlier, the major form of financial repression is currently via obligatory reserve requirements (Caprio et al. (2001)).

${ }^{3}$ See Roubini and Sala-i-Martin (1992), Rousseau and Wachtel (2002), Agbetsiafa (2004), Acaravci and Ozturk (2007) and Bose et al. (2007).
} 
(1999)) and asymmetric information (Gupta (2006)) and banking crisis (Gupta (2005)), besides, productive public expenditure (Basu (2001)) and bureaucratic corruption (Gupta and Ziramba (2008a)), currency substitution (Gupta (2008a) and, finally, costly of tax enforcement (Gupta and Ziramba (2008b)).

In fact, the motivation for this study emanates from Gupta and Ziramba (2008b). The authors, in this study, using an overlapping generations model for a production economy characterized by costly tax enforcement and financial repression, showed that, with public expenditures affecting utility of the agents, modest costs of tax collection tend to result in financial repression being pursued as an optimal policy by the consolidated government. However, when public expenditures are purposeless, the above result only holds for relatively higher costs of tax collection. But, more importantly, costs of tax collection cannot produce a monotonic increase in the reserve requirements, what are critical, in this regard, are the weights the consumer assigns to the public good in the utility function and the size of the government.

Our objective in this paper is not only check whether the results of Gupta and Ziramba (2008b) continue to hold under the assumption of endogenous growth, with the endogeneity in the growth process being obtained through productive public expenditure (Barro (1990)), but also, and perhaps more importantly, we would want to analyze if our model, by adding a supply-side to the economy, could produce a monotonic relationship between the reserve requirements and the costs of tax collection. This paper, thus, extends the work of Gupta and Ziramba (2008b). To validate our analysis, and given that the welfare optimization problem in the model is a non-linear one, as in Gupta and Ziramba (2008b), the theoretical model is numerically analyzed by calibrating it to a world economy. It must, however, be noted that our model is a general one and can be applied to any economy subjected to financial repression and costly tax enforcement. To the best of our knowledge, this is the first attempt to analyze costly tax collection as a rationale for financial repression in an economy with productive public expenditures.

Alternatively, the current study can also be viewed as an analysis that looks into the optimal mix of explicit and implicit taxation of a consolidated government in the presence of costs of collecting direct taxation. In this regard, this paper is comparable to Agénor and Neanidis (2007). In this paper, the authors show that in the presence of positive and endogenous cost of tax collection, i.e., with the cost of tax collection depending on the resources spent by the government to improve monitoring of tax payers, growth-maximizing direct and (consumption) indirect taxation are negatively related to their respective (and cross) costs of tax collection. However, the growthmaximizing value of the consumption tax rate is zero when collection costs do not exist, and, hence, the government relied completely on direct taxes. Further, with no costs of tax collection, the welfare optimizing outcome indicated the direct and consumption taxes to be substitutable, which was also the case with exogenous cost of tax collection. Finally, under exogenous costs of tax enforcement, the growth-maximizing consumption taxation was found to be negatively related to its "own" degree of inefficiency in collecting indirect taxation, and an increase in collection costs associated with direct (indirect) taxation led to a reduction (increment) in the optimal income tax rate. We, by adding money to the model, analyze the role of seigniorage (the implicit tax) relative to the explicit direct tax in the presence of cost of tax enforcement. Thus, though the main motive of our analysis is to relate financial repression with cost of tax collection, our study, in general, is quite similar to what Agénor and Neanidis (2007) do, especially, in terms of the issues, we address, on 'optimal' explicit and implicit taxation when there are costs involved in raising direct taxes. Note, our framework as well as our results, unlike that of Gupta and Ziramba (2008b), are more comparable to that of Agénor and Neanidis (2007), since it includes growth. The remainder of the paper is organized as follows: Section 2 outlines the economic environment; Section 3, 4 and 5 respectively, are devoted to defining the competitive equilibrium, discussing the process of calibration, and analyzing the welfare-maximizing choices of policy following an increase in the cost of tax collection. Finally, Section 6 concludes.

\section{ECONOMIC ENVIRONMENT}

The economy is populated by four types of agents, namely, consumers, firms, banks (financial intermediaries), and an infinitely-lived government. Time is divided into discrete segments, and is indexed by $t=1$, $2, \ldots \ldots$. There are four types of economic activities: (i) each two-period lived overlapping generations household (consumer/worker) is endowed with one unit of labor when young, but the agent retires when old. Thus, at time t, there are two coexisting generations of young and old. $N$ people are born at each time point $t=1$. At $t=1$, there 
exist $N$ people in the economy, called the initial old, who live for only one period. The population $N$ is normalized to 1 . The young inelastically supplies one unit of the labor endowment to earn wage income, which is deposited into banks for future consumption; (ii) the banks simply convert one period deposit contracts into loans, after meeting the cash reserve requirements. No resources are assumed to be spent in running the banks; (ii) each producer is infinitely lived and is endowed with a production technology to manufacture a single final good, using the inelastically supplied labor, physical capital and credit facilitated by the financial intermediaries, and; (iv) there is an infinitely lived government which meets its expenditure by taxing income and controlling the inflation tax instruments --the money growth rate and the reserve requirements. There is a continuum of each type economic agents with unit mass.

The sequence of events can be outlined as follows: A young household works in a firm and receives wages; the net of tax wage income is then deposited into the banks. A bank, after meeting the reserve requirement, provides loan to a goods producer, which subsequently manufactures the final good and returns the loan with interest. Finally, the banks pay back the deposits with interest to households at the end of the first period, and the latter consumes in the second period.

\section{Consumers}

Each consumer possesses a unit of time endowment which is supplied inelastically, and consumes only when old. Formally the problem of the consumer can be described as follows: The utility of a consumer born at $t$ depends on real consumption, $c_{t+1}$ which implies that the consumer consumes only when old. This assumption makes computation tractable and is not a bad approximation of the real world (see Hall (1988)). Consumers have the same preferences so there exists a representative consumer in each generation.

Formally, the agent's problem, born in period $t$, is as follows:

$U_{t}=U\left(c_{t+1}\right)$

where $\mathrm{U}$ is the utility function and is twice differentiable; $u^{\prime}>0 ; u^{\prime \prime}<0$ and $u^{\prime}(0)=\infty$. The utility function is maximized subject to:

$$
\begin{aligned}
& p_{t} d_{t}=\left(1-\tau_{t}\right) p_{t} w_{t} \\
& c_{t+1}=\frac{p_{t}}{p_{t+1}}\left(1+i_{d t+1}\right) d_{t}
\end{aligned}
$$

Specifically we use the following utility function:

$$
U\left(c_{t+1}\right)=\frac{c_{t+1}^{1-\sigma}}{1-\sigma}
$$

where $d_{t}$ are the real deposits held in period $t ; \tau_{t}$ is the tax rate at period $t ; p_{t}$, is the price of the consumption good at period $t ; i_{d t+1}$ is the nominal interest rate on bank deposits. Each unit of the consumption good placed into deposits at date $t$ yields $\left(1+r_{d t+1}\right)=\frac{\left(1+i_{d t+1}\right)}{1+p i_{t+1}}$ with $\left(1+\pi_{t+1}\right)=\frac{p_{t+1}}{p_{t}}$ as the gross inflation rate. 


\section{Financial Intermediaries}

Financial intermediaries provide a simple pooling function by accepting deposits at the beginning of each period. They then make their portfolio decisions (that is, loans and cash reserve choices) with a goal of maximizing profits. At the end of the period, they receive their interest income from the loans made and meet the interest obligations on the deposits received. For simplicity bank deposits are assumed to be one period contracts. The intermediaries are constrained by legal requirements on the choice of their portfolio (that is, reserve requirements), as well as by feasibility. Given such a structure, the intermediaries obtain the optimal choice for $L_{t}$ by solving the following problem:

$$
\max _{L, D} \Pi_{b}=i_{l t} L_{t}-i_{d t} D_{t}
$$

s.t. : $\gamma_{t} D_{t}+L_{t} \leq D_{t}$

where $\Pi_{b}$ the profit is function for the financial intermediary, and $M_{t} \geq \gamma_{t} D_{t}$ defines the legal reserve requirement. $M_{t}$ is the cash reserves held by the bank; $L_{t}$ is the loans; $i_{l t}$ is the interest rate on loans, and; $\gamma_{t}$ is the reserve requirement ratio. The reserve requirement ratio is the ratio of required reserves (which must be kept in the form of currency) to deposits received. To gain some economic intuition of the effect of reserve requirements on the banking sector, let us consider the solution of the problem for a typical intermediary. It is assumed that financial intermediaries behave competitively and free entry drives profits to zero,

$$
i_{l t}\left(1-\gamma_{t}\right)-i_{d t}=0
$$

Simplifying, in equilibrium, the following condition must hold

$$
i_{l t}=\frac{i_{d t}}{1-\gamma_{t}}
$$

Reserve requirements, thus, tend to induce a wedge between the interest rate on savings and lending rates for the financial intermediaries.

\section{Firms} technology:

All firms are identical and produce a single final good using the following Cobb-Douglas-type production

$$
y_{t}=A k_{t}^{\alpha}\left(n_{t} g_{t}\right)^{(1-\alpha)}
$$

where A $>0 ; 0<\alpha((1-\alpha))<1$, is the elasticity of output with respect to capital (labor), where $k_{t}, n_{t}$ and $g_{t}$ respectively denoting capital, labor, and government expenditure inputs at time $t$. At time $t$ the final good can either be consumed or stored. We assume that producers are able to convert bank loans $L_{t}$ into fixed capital formation such that , $p_{t} i_{k t}=L_{t}$, where $i_{k t}$ denotes the investment in physical capital. The production transformation schedule is linear so that the same technology applies to both capital formation and the production of the consumption good and, hence, both investment and consumption good sell for the same price $p$. We follow Diamond and Yellin (1990) and Chen, Chiang and Wang (2000) in assuming that the goods producer is a residual claimer, that is, the producer uses up the unsold consumption good in a way which is consistent with lifetime value maximization of the firms. This assumption regarding ownership avoids the "unnecessary" Arrow-Debreu 
redistribution from firms to consumers and simultaneously retains the general equilibrium structure of the models.

The representative firm maximizes the discounted stream of profit flows subject to the capital evolution and loan constraint. Formally, the problem of the firm can be outlined as follows

$\max _{k_{t+1}, n_{t}} \sum_{i=0}^{\infty} \rho^{i}\left[p_{t} y_{t}-p_{t} w_{t} n_{t}-\left(1+i_{l t}\right) L_{t}\right]$

$k_{t+1} \leq\left(1-\delta_{k}\right) k_{t}+i_{k t}$

$p_{t} i_{k t} \leq L_{t}$

$L_{t} \leq\left(1-\gamma_{t}\right) D_{t}$

where $\rho$ is the firm owners (constant) discount factor, and $\delta_{k}$ is the (constant) rate of capital depreciation. The firm solves the above problem to determine the demand for labor and investment. The firm's problem can be written in the following respective recursive formulations:

$$
V\left(k_{t}\right)=\max _{n, k^{\prime}}\left[p_{t} A k_{t}^{\alpha}\left(n_{t} g_{t}\right)^{(1-\alpha)}-p_{t} w_{t} n_{t}-p_{t}\left(1+i_{l t}\right)\left(k_{t+1}-\left(1-\delta_{k}\right) k_{t}\right)\right]+\rho V\left(k_{t+1}\right)
$$
conditions.

The upshots of the above dynamic programming problems are the following respective first order

$$
\begin{aligned}
& k_{t+1}:\left(1+i_{l t}\right) p_{t}=\rho p_{t+1}\left[A \alpha\left(\frac{g_{t+1}}{k_{t+1}}\right)^{1-\alpha}+\left(1+i_{l t+1}\right)\left(1-\delta_{k}\right)\right] \\
& \left(n_{t}\right): A(1-\alpha)\left(\frac{g_{t}}{k_{t}}\right)^{(1-\alpha)} k_{t}=w_{t}
\end{aligned}
$$

Equation (15) provides the condition for the optimal investment decisions of the firm. The firm compares the cost of increasing investment in the current period with the future stream of benefits generated from the extra capital invested in the current period. And equation (16) states that the firm hires labor up to the point where the marginal product of labor equates the real wage.

\section{Government}

The government is assumed to be infinitely-lived. It purchases $g_{t}$ units of the consumption good. Government expenditures are productive to the agents. Government expenditures are financed through income taxation and seigniorage. The government faces explicit costs of raising taxes, $\frac{1}{2} \phi \tau_{t}^{2} w_{t}$. As in Agénor and Neanidis (2007), we assume these costs to be increasing with the tax rate (at an increasing rate) and the wage rate. In real percapita terms the government budget constraint can be written as follows:

$g_{t}=\tau_{t} w_{t}+\frac{M_{t}-M_{t-1}}{p_{t}}-\frac{1}{2} \phi \tau_{t}^{2} w_{t}$

with $M_{t}=\left(1+\mu_{t}\right) M_{t-1}$ and $\phi \geq 0$, where $\mu$ is the net money growth rate and $\phi$ is the cost parameter. Note, 
the consolidated government coordinates the activities of the treasury and the central bank, both of which are "equally subservient to the government". The benevolent government maximizes the steady-state level of welfare for all future generations, obtained by substituting the equilibrium decision rules into the agents' utility function to determine the optimal levels of the policy variables.

\section{EQUILIBRIUM}

A competitive equilibrium for this economy is a sequence of prices $\left\{p_{t}, i_{d t}, i_{l t}\right\}_{t=0}^{\infty}$, allocations $\left\{c_{t+1}, n_{t}, i_{k t}\right\}_{t=0}^{\infty}$, stocks of financial assets $\left\{m_{t}, d_{t}\right\}_{t=0}^{\infty}$, and policy variables $\left\{\gamma_{t}, \mu_{t}, \tau_{t}, g_{t}\right\}_{t=0}^{\infty}$ such that:

- $\quad$ The consumer maximizes utility given by (1) subject to (2) and (3);

- $\quad$ Banks maximize profits, taking $i_{l t}, i_{d t}$, and $\gamma_{t}$ as given and such that (8) holds;

- $\quad$ The real allocations solve the firm's date- $t$ profit maximization problem, given prices and policy variables, such that (15) and (16) hold;

- $\quad$ The money market equilibrium conditions: $m_{t}=\gamma_{t} d_{t}$ is satisfied for all $\mathrm{t} \geq 0$;

- The loanable funds market equilibrium condition: $p_{t} i_{k t}=\left(1-\gamma_{t}\right) D_{t}$ where the total supply of loans $L_{t}=\left(1-\gamma_{t}\right) D_{t}$ is satisfied for all $\mathrm{t} \geq 0$;

- $\quad$ The goods market equilibrium condition require: $c_{t}+i_{k t}+g_{t}=y_{t}-\frac{1}{2} \phi \tau_{t}^{2} w_{t}$ is satisfied for all $\mathrm{t} \geq 0$;

- $\quad$ The labor market equilibrium condition: $\left(n_{t}\right)^{d}=1$ for all $\mathrm{t} \geq 0$;

- $\quad$ The government budget is balanced on a period-by-period basis;

- $\quad d_{t}, i_{d t}, i_{L t}$, and $p_{t}$ must be positive at all dates.

\section{CALIBRATION}

In this section, we discuss how we assign values to the parameters of our model, based on a combination of figures from previous studies and those that we calibrate. The problem of the social planner is non-linear in $\tau, \gamma$, and $\mu$, and, hence, cannot be solved analytically. Numerical solution of the problem, in turn, requires values for the structural parameters of the model, and, hence, the calibration. Following the standard real business cycle literature, we use steady-state conditions to establish parameter values observed in the data. Some parameters are calibrated using world economy data, while others correspond to prevailing values from the literature. This section reveals the general procedures used.

A first set of parameter values is given by numbers usually found in the literature. The following parameter values were chosen initially and the specific source is mentioned in the parentheses given aside, except for the standard ones. These are:

- $\quad \sigma:$ the degree of risk aversion, as stated above, was set to 2 ;

- $\quad \alpha$ : since the production function is Cobb-Douglas, this corresponds to the share of capital in income. The value chosen was of 0.70 (Basu (2001)); 
- $\quad \delta_{k}$ : the depreciation rate of physical capital was set at 0.05 or 5 percent (Zimmermann (1994));

- $\quad \gamma$ : the annual reserve-deposit ratio was fixed at 0.15 (Haslag and Young (1998));

- $\quad \tau$ : tax rate was set to 0.25 or 25 percent (Chari et al. (1995));

- $\pi$ : the annual rate of inflation was fixed at 5 percent, and, hence, the gross rate of inflation was $1+\pi=1.05$ (Basu (2001));

- $\quad i_{l t}$ : the nominal interest rate on loans was set to 0.15 or 15 percent (Gupta (2008a));

- $\quad \beta$ : the discount rate, is set to 0.98 (Chari et al. (1995)).

A second set of parameters are calibrated from the steady-state equations of the model to make them hold exactly: These parameters are:

- $\phi$ : the cost of tax enforcement. Based on $\tau=25.00$ percent, $\gamma=15.00$ percent, yields a value of $\phi=$ 33.66 percent, when we take into account that costs of tax collection amounts to 3 percent of total revenue in developing countries (Bird and Zolt (2005) and Agénor and Neanidis (2007)). We also set this value at 0 (benchmark case), $0.05,0.1$ for the policy experiments discussed in the next section;

- $\quad \frac{g}{k}$ : the ratio of government expenditure to capital. Given the values of $\tau, \gamma, \mu$, and $\phi$, this was calibrated from the government budget constraint and has a value of 0.0714 .

- $\quad \chi=\left\{A(1-\alpha)(1-\gamma)(1-\tau)\left(\frac{g}{k}\right)^{1-\alpha}-\delta\right\}:$ the net growth rate which is set equal to 2.5 percent (Basu (2001));

- $\quad 1+\mu$ : the gross money growth rate is calibrated using the money market equilibrium which implied that $1+\mu=1+\chi \times 1+\pi$. This resulted in the net money growth rate to be equal to 0.076 or 7.6 percent;

- $\quad \rho$ : the discount factor of the firms is solved to ensure that equation (15) holds and is equal to 0.8011 ;

- $A$ : the value of the production function scalar, is calibrated from the equilibrium conditions to match the growth rate of 2.5 percent and an inflation rate of 5 percent and is equal to 0.8659 .

\section{OPTIMAL POLICY DECISIONS}

In this section, we analyze the optimal policies for the government in the face of a rise in the cost of tax collection. For this purpose, we study the behavior of a benevolent government or social planner who maximizes the utility of all consumers, evaluated at the steady state, by choosing $\gamma, \tau$ and $\mu$, following alternative values of $\phi$. Specifically, the problem for the social planner is captured by: $\sum_{i=0}^{\infty} \beta^{i} U\left(c_{t+1+i}\right)$ subject to inequality constraints $\tau \geq 0, \tau \leq 1 ; \gamma \geq 0, \gamma \leq 1 ; \mu \geq 0$. Furthermore, as in Basu (2001), we will assume that the government follows time invariant policy rules, which means that the institutionally determined tax rate, $\tau_{t}$, the cash reserve ratio, $\gamma_{t}$, the money growth rate, $\mu_{t}$ are constant over time. 
For deducing whether financial repression is positively correlated with the cost of tax enforcement, we start off with our benchmark case of $\phi=0$. Finally, to check for the robustness of our results, we also use $\phi=0.05$ and $\phi=0.1$, besides, $\phi=0.3366$.

The results of the policy experiments have been reported in Table 1. Column 1 of the table reports the alternative sizes of the cost parameter. Columns 2 to 4 report the optimal values of $\tau, \gamma$ and $\mu$ respectively, under $\phi=0.00,0.05,0.10$ and 0.3366 , respectively. ${ }^{4}$

Table 1: Optimal Policy Decisions

\begin{tabular}{|c|c|c|c|c|}
\hline Cost parameter & $\gamma^{*}$ & $\mu^{*}$ & $\tau^{*}$ & Seigniorage/tax \\
\hline$\phi=0.00$ & 33.68 & 257.01 & 50.93 & 11.90 \\
\hline$\phi=5.00$ & 70.34 & 161.90 & 36.09 & 27.86 \\
\hline$\phi=10.00$ & 74.81 & 139.06 & 28.06 & 31.31 \\
\hline$\phi=33.66$ & 77.36 & 129.32 & 22.25 & 33.92 \\
\hline
\end{tabular}

(i) Parameters defined as above

(ii) All values are in percentages.

One can draw the following general conclusions from Table 1:

- The government optimally reduces the tax rate in response to rising costs of tax collection. Note in Gupta and Ziramba (2008b), for $\phi=0$, the tax rate was equal to either the share of the public good in the utility function or equal to size of the government, depending on whether government expenditures were useful or purposeless. Higher values of the cost parameter caused the optimal tax rate to fall to zero; ${ }^{5}$

- Just as the tax rate, the money supply growth rate (rate of inflation tax) tends to fall. However, also note that the value of the money growth rate is always very high. This, though, is a widely observed feature in models analyzing welfare-maximizing policies. ${ }^{6}$ In the Gupta and Ziramba (2008b) framework, money growth rate was always optimally set at infinity in the case where public expenditure was productive, but was equal to zero in the case of purposeless public expenditure, until the reserve requirement became positive;

- As the cost of tax enforcement rises, reserve requirements, or alternatively, the metric for financial repression, increases as part of an welfare maximizing outcome;

- $\quad$ Importantly note, unlike Gupta and Ziramba (2008b), higher costs of tax collection produces a monotonic increase in financial repression. In the pure-exchange model of Gupta and Ziramba (2008b), as long as the tax rate was positive, the reserve requirements continued to be equal to zero. Once higher costs of tax collection ensured an optimal tax rate of zero, the reserve requirement moved with either the share of the public good in the utility function or the size of the government, depending on whether government expenditures were useful or purposeless ;

- So, as far as, the reliance on indirect taxation, in our case seigniorage, is concerned, we show that as the cost of tax collection increases, the ratio of seigniorage to total revenue increases as part of an welfare-

\footnotetext{
${ }^{4}$ The movement of the optimal policy variables continue to hold for values of $\phi$ higher than 0.3366 . However, given that the obtained value is derived from empirical evidence, we do not report our results beyond it. Further, our results were also found robust to alternative values of $\alpha$ and when we allowed only a fraction of government expenditure to be productive.

${ }^{5}$ In Gupta and Ziramba (2008b), relatively, higher value of the cost parameter was required to produce a zero tax rate, under the case of purposeful public expenditures.

${ }^{6}$ See Bhattacharya and Haslag (2001) for further details.
} 
maximizing outcome. Interestingly, in Agénor and Neanidis (2007), the welfare optimizing outcome indicated the direct and consumption taxes to be substitutable, irrespective of whether the exogenous cost of tax collection was zero or positive.

- $\quad$ Our results, are, however, partially comparable when we consider the case of positive and endogenous cost of tax collection discussed in Agénor and Neanidis (2007). The authors show that growth-maximizing direct and (consumption) indirect taxation are negatively related to their respective (and cross) costs of tax collection. However, the growth-maximizing value of the consumption tax rate is zero when collection costs do not exist, and, hence, the government relied completely on direct taxes. As can be seen from Table 1 , our results, indicate a positive relationship between the cost of collecting direct tax and the size of seigniorage to total revenue, but, unlike Agénor and Neanidis (2007), we continue to have a non-zero reliance on indirect taxation even when cost of tax collection for direct taxes is equal to zero. But then again, unlike them, our results are based on a welfare optimizing outcome. Note in Gupta and Ziramba (2008b) this was not the case. In that study, movements of the policy variables were not monotonic, neither was the ratio of indirect to direct taxation. The movement in this ratio depended crucially on the size of the government or the weight on the public good in the utility function.

So, in summary, by incorporating a production sector, and, hence, extending the endowment economy model of Gupta and Ziramba (2008b), allows us to produce a monotonic positive relationship between financial repression and costly tax enforcement. Though note, even when there does not exist any cost of tax collection $(\phi=$ 0 ), the government relies on a positive level of seigniorage, and, thus positive levels of money growth rate and the reserve requirement, unlike Gupta and Ziramba (2008b). Further, the share of seigniorage to tax revenue continues to increase as the value of $\phi$ increases.

Intuitively, the obtained results make sense. An increase in the cost of direct tax collection, results in the fall in the growth rate due to a decline in the productive effect of the government expenditure, which, in turn, reduces welfare. The government responds by reducing the tax rate, which, in turn, boosts savings and causes higher growth rate and higher welfare. However, a reduction in the tax rate results in the fall of government revenue and tends to have a negative indirect impact on growth and welfare. To restore the size of the government revenue, the planner, increases seigniorage by increasing the reserve requirement. But given that increases in the reserve requirement tends to reduce the real interest rate on deposits and, thus, welfare, the government compensates this move by reducing the money growth rate, and, hence, increasing the real interest rate, in such a way that the loss in revenue for a reduction in the money growth rate, does not reduce growth and affect welfare indirectly. It must, however, be realized that all these changes occur simultaneously, and the government chooses the policy instruments taking into account the direct and indirect effects on welfare following an increase in the degree of corruption.

\section{CONCLUSION}

Using a dynamic general equilibrium overlapping generations monetary endogenous growth model of a financially repressed economy characterized by costly tax enforcement and productive public expenditures, we analyze whether the cost tax collection can result in a monotonic increase in financial repression, with the latter being modeled through an obligatory "high" reserve deposit ratio requirement, that the banks in the economy need to maintain. In other words, this study attempts to assay whether costly tax enforcement can provide a rational for financial repression. But more generally, the study also attempts to find the optimal-mix of monetary and fiscal policies of a benevolent government, following an increase in the cost of tax collection.

When numerically analyzed for a world economy, the following basic conclusions could be drawn: (i) Unlike Gupta and Ziramba (2008b), where beyond a threshold value, positive cost of tax collection resulted in financial repression, but costs of tax collection and financial repression did not possess a monotonic positive relationship, we find a positive monotonic relationship between the two, with the government relying on a positive level of seigniorage, even when there is no positive costs of tax collection, and; (ii) The paper shows that a benevolent social planner would rely more on seigniorage relative to the income tax as the cost of tax enforcement increases. Clearly then, cost of direct tax collection can serve as a rationale for the existence of financial repression. 


\section{AUTHOR INFORMATION}

Rangan Gupta is currently an Associate Professor at the Department of Economics, University of Pretoria. After having completed his Ph.D. in May 2005 from the Department of Economics, University of Connecticut, he joined the Department of Economics, University of Pretoria, as a Senior Lecturer in August 2005. He secured my BSc (Honours) degree from the R.K.M.R. College, Narendrapur, and the MSc degree from the University of Calcutta. His academic interests are mainly Monetary Theory and Policy, Business Cycles, and Time Series Econometrics.

Emmanuel Ziramba is currently a Senior Lecturer at the Department of Economics, University of South Africa. He joined the University of South Africa as a lecturer on 1 March 2004 and was promoted to his current position on the $1^{\text {st }}$ of January 2008. He completed his Ph.D. in April 2009 from the Department of Economics, University of Pretoria. He secured his BSc (Honours) and the MSc degrees from the University of Zimbabwe. His academic interests are mainly International Trade and Finance, Defence Economics, and Time Series Econometrics.

\section{REFERENCES}

1. Acaravci, A., and Ozturk, I. (2007), Finance-Growth Nexus: Evidence from Turkey, International Research Journal of Finance and Economics pp. 30- 40.

2. Agbetsiafa, D. (2004), The Finance Growth Nexus: Evidence from Sub-Saharan Africa, Savings and Development 28(3): 271-288.

3. Agenor, P-R., and Neanidis, K. C. (Oct. 2007.) Optimal Taxation and Growth with Public Goods and Costly Enforcement. University of Manchester Discussion Paper Series Number 087.

4. Bacchetta, P., and Caminal, R.(Oct. 1992.) Optimal seigniorage and financial liberalization. Journal of International Money and Finance 11(5): 518-538.

5. Barro, R. J. (Oct. 1990.) Government spending in a simple model of endogenous growth. Journal of Political Economy, 98(5, Part - 2): S103-S125.

6. $\quad$ Basu, P. (2001.) Reserve Ratio, Seigniorage and Growth. Journal of Macroeconomics 23(3), 397-416.

7. Bhattacharya, J., and Haslag, J. H. (Oct. 2001) On the use of inflation tax when non-distortionary taxes are available. Review of Economic Dynamics, 4(4): 823-841.

8. Bird, R. M., and Zolt, E. M. (Dec 2005.) The Limited Role of the Personal Income Tax in Developing Countries. Journal of Asian Economies, 16: 928-946.

9. Bose, N., Holman, J.A., and Neanidis, K. C. (2007), "The optimal public expenditure financing policy: Does the level of economic development matter?", Economic Inquiry, 45 (3)pp. $433-452$.

10. Caprio, G., Honohan, P., Stiglitz, J. E., 2001. Financial liberalization: How far, how fast? Cambridge University Press, Cambridge, UK.

11. Chang, R., L. Kaltani, N. Loayza. (2005) Openness can be good for growth: The role of policy complementarities. NBER Working Paper Series. Working paper number 11787.

12. Chari, V.V., Manuelli, R.E., and Jones, L.E. (1995.) The Growth Effects of Monetary Policy. Quarterly Review, Federal Reserve Bank of Minneapolis 19(4), 18-32.

13. Chen, B. L., Chiang, Y. Y., and Ping, W. (Jun. 2000.) Credit market imperfections, financial activity and economic growth. Working Paper No. 00-W20, Vanderbilt University.

14. Del Monte, A., and Papagni, E. (2001.) Public Expenditure, corruption, and economic growth: the case of Italy. European Journal of Political Economy 17, 1-16.

15. Cuikerman, A., Sebastian, E., and Tabellini, G. (Jun. 1992.) Seigniorage and political instability. American Economic Review 82(3): 537-555.

16. Di Giorgio 1999. Financial development and reserve requirements. Journal of Banking and Finance 23, 1031-1041.

17. Diamond, P. and Yellin, J. (July 1990.) Inventories and Money Holdings in a Search Economy. Econometrica, 58(4):929-950.

18. Drazen, A. (1989.) Monetary Policy, Seigniorage, and Capital Controls in an Open Economy. In An European Central Bank? (M. de Cecco and A. Giovannini, eds.) Cambridge: Cambridge University Press, pp. 13-52.

19. Espinosa, M., and Yip, C. K. (Jun. 1996.) An endogenous growth model of money, banking, and financial repression. Working Paper No. 96-4, Federal Reserve Bank of Atlanta. 
20. Gallagher, M., (Jun. 2005.) Benchmarking Tax Systems. Public Administration and Development, 25: 125144.

21. Giovanni, A., and De Melo, M. (Sep. 1993.) Government revenue from financial repression. American Economic Review 83(4): 953-963.

22. Gupta, R., (Nov. 2005.) Costly state monitoring and reserve requirements. Annals of Economics and Finance, 6(2): 263-288.

23. Gupta, R., (Feb. 2006.) Asymmetric information, tax evasion and alternative instruments of government revenue. The ICFAI Journal of Monetary Economics, IV(1): 75-89.

24. Gupta, R. (2008a.) Currency substitution and financial repression. Working Paper 06, Department of Economics, University of Pretoria.

25. Gupta, R. (2008b.) Tax evasion and financial repression. Journal of Economics and Business, 60(6) $517-$ 535 .

26. Gupta, R. and Ziramba, E. (2008a.) Openness, Bureaucratic Corruption and Public Policy in an endogenous growth models. Working Paper 17, Department of Economics, University of Pretoria.

27. Gupta, R. and Ziramba, E. (2008b.) Costly tax Enforcement and Financial Repression. Economic Notes: Review of Banking, Finance and Monetary Economics, vol.37, no.2, pp. 141-154.

28. Gupta, R. and Ziramba, E. (2009.) Tax evasion and financial repression: A reconsideration using endogenous growth models. Journal of Economic Studies, volume 36 issue 6.

29. Haslag, J. H. (Jul. 1998.) Monetary policy, banking and growth. Economic Inquiry XXXVI(3): 489-500.

30. Haslag, J. H., and Hein, S. E. (Apr. 1995.) Does it matter how monetary policy is implemented?. Journal of Monetary Economics 35(2): 359-386.

31. Haslag, J. H., and Koo, J. (1999.) Financial repression, financial development and economic growth. Working Paper No. 99-02, Federal Reserve Bank of Dallas.

32. Haslag, J. H., and Young, E. R. (Jul. 1998.) Money creation, reserve requirements, and seigniorage. Review of Economic Dynamics. 1(3): 677-698.

33. Holman, J. A., Neanidis, K. C., 2006. Financing government expenditure in an open economy. Journal of Economic Dynamics and Control, 30: 1315-1337.

34. Roubini, N., and Xavier, Sala-i-Martin. (Jul. 1992.) Financial repression and economic growth. Journal of Development Economics 39(1): 5-30.

35. Roubini, N., and X. Sala-i-Martin, (Apr. 1995.) A growth model of inflation, tax evasion, and financial repression. Journal of Monetary Economics, 35(2): 275-301.

36. ROUSSEAU, P.L and P. WACHTEL. (2002), Inflation thresholds and the finance-growth nexus, Journal of International Money and Finance 21(6): 777- 793. 
NOTES 